International Research Journal of Management, IT \& Social Sciences
Available online at https://ijcujournals.us/journals/index.php/irjmis
Vol. 6 No. 1, January 2019, pages: 33 41
ISSN: 2395-7492
https://doi.org/10.21744/irjmis.v6n1.481

\title{
College Student Attitude towards Social Media
}

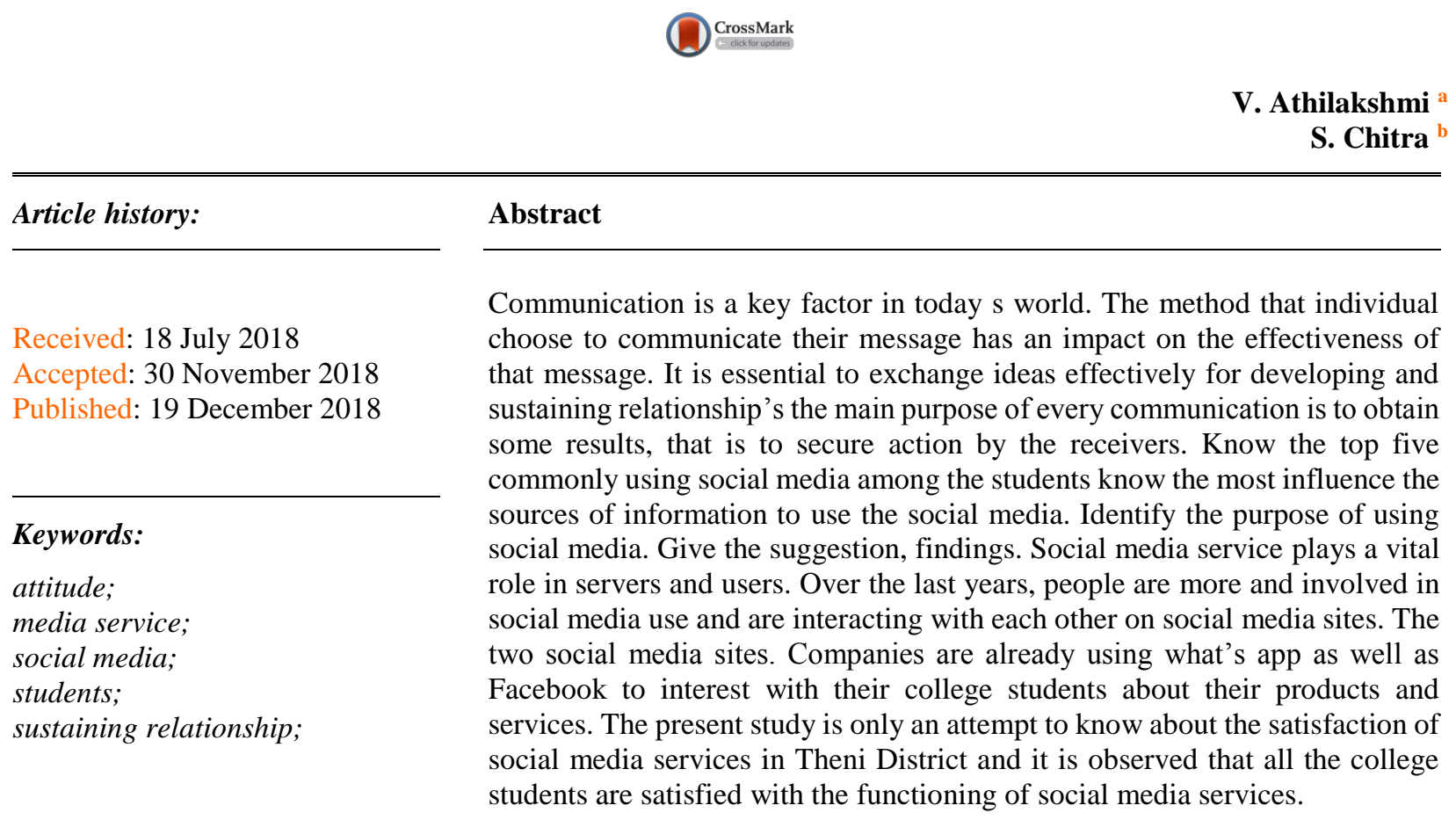

2395-7492@ Copyright 2019. The Author. Published by SLOAP. This is an open-access article under the CC-BY-SA license (https://creativecommons.org/licenses/by/4.0/) All rights reserved.

\section{Author correspondence:}

V. Athilakshmi,

Ramakrishna puram Pottipuram (po)

Email address: vathilakshmi.1996@gmail.com

\section{Introduction}

Cheung et al., (2011), Fogel \& Nehmad (2009), Communication is a key factor in today s world. The method that individual choose to communicate their message has an impact on the effectiveness of that message. It is essential to exchange ideas effectively for developing and sustaining relationship's the main purpose of every communication is to obtain some results, that is to secure action by the receivers.

Communication can do in the acceleration of the growth of the economy by transmitting information and simplifying motivation. Mobility is a fantastic facility possessed by a man that helps him to explore the places and thus provides a way for his survival. This plays an important role in the developing of human civilization communication has been playing a pivotal role in one's life from time immemorial. Inventions like radio television, the telephone and the computer made tremendous changes in the world.

\footnotetext{
a Ramakrishna puram Pottipuram, Theni, India

${ }^{\mathrm{b}}$ Nadir Saraswathi college of Arts and Science, Theni, India
} 
Nowadays, the social network plays a vital role in the world. The social network is the practice of exploring the number of one's business and or social contacts by making the connection. Through individuals, while social networking has gone on almost as long as societies themselves have existed, the unpatrolled potential of the intent to promotes such connection only now being fully recognized and exploited. Through web-based groups established for that purpose.

\section{Social Media}

Social media are computer-mediated technologies that facilitate the creation and sharing of information, ideas, career interests and other forms of expression via virtual communities and networks. The variety of stand-alone and built-in social media services currently available introduces challenges of definition; however, there are some common features:

1) Social media are interactive Web 2.0 Internet-based applications.

2) User-generated content, such as text posts or comments, digital photos or videos, and data generated through all online interactions, is the lifeblood of social media.

3) Users create service-specific profiles for the website or app that are designed and maintained by the social media organization.

4) Social media facilitate the development of online social networks by connecting a user's profile with those of other individuals or groups.

5) Users typically access social media services via web-based technologies on desktop, computers, and laptops, or download services that offer social media functionality to their mobile devices (e.g., smartphones and tablet computers). When engaging with these services, users can create highly interactive platforms through which individuals, communities and organizations can share, co-create, discuss, and modify user-generated content or pre-made content posted online. Some of the most popular social media websites are BaiduTieba, Facebook (and its associated Facebook Messenger), Gab, Google+, MySpace, Instagram, LinkedIn, Pinterest, Tumblr, Twitter, Viber, VK, WeChat, Weibo, WhatsApp, Wikia, Snapchat and YouTube. These social media websites have more than 100,000,000 registered users.

\section{Statement of the Problem}

Profit earning has become one of the important objectives of each and every company. It is very easy to attract new customer but retaining an old customer is too difficult only the satisfied customer will remain loyal to the firm brands. A person when they want to use applications in our mobile phone, but before uses the apps they consult so many people about the application. Like about price, quality, service etc., and then he makes the decision to use. If he finds any problem with apps, he may change his positive attitude into negative towards apps given by the service. Considering, all the above points, I have decided "to A study on college students attitude towards social media in Theni district.

\section{Objectives}

1) To know the top five commonly using social media among the students.

2) To know the most influence the sources of information to using the social media.

3) To identify the purpose of using social media.

4) To give the suggestion, findings.

The scope of the Study

The following are the scope of the study:

1) The Study was conducted in Theni district which is an agriculture-based district.

2) It was only an attempt to study the operational efficiency of various services provided by social networks to the college students.

3) The study area consists of five Taluk of Theni district.

4) It is based on a sample of 80 respondents of mobile application users. 
Review of literature

Survey of literature takes an important part in all researches and it is a systematic quest for available truth on a particular topic. It is very useful to know has happened in the particular topic and what has been found out in future research. The researcher can understand the gap in which aspect no research has been undertaken in the past period. In this way, such survey takes an important a brief summary of review or literature - college students attitude

Geria et al., (2018), Kim et al., (2011), Perceptions of Social Media Impact on Students' Social Behavior: A Comparison between Arts and Science Students presented by L. Al-Sharqi K. Hashim I. Kutbi Center for Strategic Studies King Abdulaziz University Jeddah, Saudi Arabia international Journal of Education and Social Science Vol. 2 No. 4; April 2015 122." KAU students are familiar with and use different categories of social media. Amongst the students of Science and Arts colleges, the highest categories of social media tool usage is 'YouTube' followed by 'Twitter' and then 'Facebook'. Mao (2014), Roblyer et al., (2010), KAU students use social media tools for a blend of academic and non-academic purposes. Category 'Entertainment' represents the highest category for both college groups with about 79 percent. Second highest is category 'Information searching' and the third highest is category 'Learning' for both groups. Stutzman et al., (2011), Tess (2013), the students agree on the advantages of social media on social behavior but are unsure of the disadvantages. This paper captured the perceptions of each group.

\section{Materials and Methods}

\section{Statistical Tools}

The researcher for the interpretation of data has applied the following statistical tools. They are;

1) Percent age

2) Chi-square

\section{Percentage Method}

In this project percentage method test is used. The percentage method is used to know the accurate percentage of the data; it is easy to grid out through the percentage. The following are the formula

Percentage of respondent $=$ No. of Respondent $/$ Total No. of Respondent $* 100$

\section{Collection of Data}

For the collecting the primary data from the 80 sample respondent, the questionnaire is used the research scholar. The Questionnaire is quite informal and administrated to the respondents. The respondent filled the answer of the various question through the personal direct method with the respondent.

\section{Chi-Square}

In order to apply the chi-square test either as a test of goodness of fit or as a test to judge the significance of the association between attributes, it is necessary that the observed, as well as theoretical or expected frequencies, must be grouped in the same way and the theoretical distribution.x 2 is then calculated as follows.

$$
X 2=\sum(o j-E i j) 2 / E
$$

Where;

Oij=observed frequency of the cell in ith row and jith column

Eij=expected frequency of the cell in ith and jith column.

\section{Hypotheses}

Based on the objective of the study, the following hypothesis was framed:

1) There is no relationship between the factors influenced and level of satisfaction.

2) There is no significant difference between the social media and the level of satisfaction

Athilakshmi, V., \& Chitra, S. (2018). College student attitude towards social media. International Research Journal of Management, IT and Social Sciences, 6(1), 33-41. https://doi.org/10.21744/irjmis.v6n1.481 


\section{Results and Discussions}

\subsection{Gender}

The researcher has gathered details about the gender category of the respondents. Are made and percentage in Table 1.

Table 1

Gender wise classification

\begin{tabular}{lll}
\hline Gender & Number of respondent & Percentage of respondent \\
\hline Male & 24 & $30 \%$ \\
Female & 56 & $70 \%$ \\
Total & 80 & 100 \\
\hline
\end{tabular}

Source: Primary data

Table 1 shows that, out of 80 respondents taken for the study, $30 \%$ of the respondent are male and $70 \%$ of the respondent is female. It is interpreted that most of the respondent (56) 70\% are female.

The age is considered an important factor for the study. The age wise classification provides information regarding the age of the respondents. It is observed that several age groups of students are using social media. The age wise classification of the respondents is given the following Table 2.

Table 2

Age wise classification of the respondents

\begin{tabular}{lll}
\hline Age & Number of respondent & Percentage of respondent \\
\hline Below 20 & 18 & $22.5 \%$ \\
$21-25$ & 51 & $63.75 \%$ \\
$26-30$ & 11 & $13.75 \%$ \\
Total & 80 & 100 \\
\hline
\end{tabular}

Source: Primary Data

Table No 4.2 represents that out of 80 respondents taken for the study, $22.5 \%$ (18) of the respondent age is below 20 and $63.75 \%(51)$ are in the respondent age group of between are $21-25.13 .75 \%$ (11) of the respondent is in the age of between 26-30. Therefore, it is interpreted that most of the respondents are in the age group between 21-25.

\subsection{Educational Status}

Educational status of the 80 respondents was analyzed and presented in the following Table 3 .

Table 3

Educational Status of the respondents

\begin{tabular}{lll}
\hline Educational & Number of Respondents & Percentage of Respondent \\
\hline Graduate & 51 & $63.75 \%$ \\
Professional & 14 & $17.5 \%$ \\
Others & 15 & $18.75 \%$ \\
Total & 80 & $100 \%$ \\
\hline
\end{tabular}

Source: Primary Data

Table No 4.4 represent that out of 80 respondents taken for the study, $15 \%$ of the respondents are school and $51.25 \%$ of the respondents are graduate. Therefore it is interpreted that most of the respondent is in the graduate status of between (51) $63.75 \%$. 


\subsection{Kinds of Social Media}

Tables 4 are shows that used our social media

Table 4

Used social media

\begin{tabular}{lll}
\hline Social media & No. of Respondent & Percentage \\
\hline What Sapp & 30 & $37.5 \%$ \\
Facebook & 22 & $27.5 \%$ \\
Twitter & 4 & $5 \%$ \\
Google & 6 & $7.5 \%$ \\
Instragram & 4 & $5 \%$ \\
YouTube & 12 & $15 \%$ \\
LinkedIn & 2 & $2.5 \%$ \\
Total & 80 & 100 \\
\hline
\end{tabular}

(Source: primary data)

Table No 4.7 represents that out of 80 respondents taken for the study, $2.5 \%$ of the respondent are used in LinkedIn and $37.5 \%$ of the respondent are used WhatsApp. Therefore it is interpreted that most of the respondent are used in WhatsApp (30)37.5\%.

\subsection{The Factor influenced to use the social media in the level of satisfaction}

Table 5 shows that the factor influenced the use of social media.

Table 5

Factor influenced the use of social media

\begin{tabular}{|c|c|c|c|c|c|c|}
\hline \multirow{2}{*}{ S.No } & \multirow{2}{*}{\multicolumn{2}{|c|}{ Factors Status }} & \multicolumn{3}{|c|}{ Number of Respondents } & \multirow{2}{*}{ Total } \\
\hline & & & High & Medium & Low & \\
\hline 1. & $\begin{array}{l}\text { Facilitate learning, } \\
\text { Knowledge, Build in } \\
\text { Easy to communication }\end{array}$ & $\begin{array}{r}\text { Gaining } \\
\text { Relationship, }\end{array}$ & 19 & 22 & 11 & 52 \\
\hline 2. & All the above & & 5 & 8 & 15 & 28 \\
\hline Total & & & 24 & 30 & 26 & 80 \\
\hline
\end{tabular}

(Source: computed data)

Degree of freedom $=2$

Calculated value $=7.49$

Table value of $x^{2}$ at 3 percent level $=5.991$

The calculated value is 7.49 and the table value for 2 degrees of freedom at 3 percentage satisfaction is one 5.991. Since the calculated value higher than by table value, the null hypothesis rejected. The null hypothesis inferred that the factor status and satisfaction level had the relationship.

\subsection{Findings}

Findings are the means to form interpretations and generalizations which provide valuables. In this regard the researcher consolidates the findings of the research.

Athilakshmi, V., \& Chitra, S. (2018). College student attitude towards social media. International Research Journal of Management, IT and Social Sciences, 6(1), 33-41. https://doi.org/10.21744/irjmis.v6n1.481 


\subsection{Profile of the Study}

The profile of the respondents is an inferred by studying the factors such as gender, age, marital status, family size, education qualification, and monthly income of a family of the respondents.

1) Out of 80 sample respondents, 24 respondents belong to the males and only 56 respondents belong to the female.

2) Out of 80 sample respondents,51 respondents belong to the age group of 21-30 years and only 18 respondents belong to the age group of below 20

3) Out of 80 sample respondents, 41 respondents during graduate and only 14responedents are belongs to professionals.

4) Married members (63) are less than the unmarried members (17) among the 80 sample respondents.

5) The study shows that out of 80 sample respondents, monthly income of a family of 80 respondents are below 25000 and only 27 respondents are an earned monthly income quantity of 25001-35000

\subsection{Level of Satisfaction towards Using Social Networking}

On the basis of five hypotheses framed by the researcher the following finding was observed:

1) There is no significant between factors influenced and level of satisfaction

2) There is no significant between social media influenced and level of satisfaction

\section{Conclusion}

Social media service plays a vital role in servers and users. Over the last years, people are more and involved in social media use and are interacting with each other on social media sites. The two social media sites. That is being used in this research are facebook and WhatsApp. Facebook exists since 2004 and it became public networking in 2006. What's app was created in 2006 and was immediately a public medium. Facebook is a social media site and what's app has elements of social media sites as well as of a blog. They rather meet their offline friends in the online world then meet people online. The like button makes it possible to comment on friend's posts but makes it also possible to follow brands, companies, and celebrities on facebook. The profile on what's app are connected through a network, people can follow others and see their tweets, but the other user doesn't need to reciprocate.

\section{Suggestion}

From the above study, the usage of social networks is through relaxing as it plays a very important role among the respondents. As such, it suggested that the title more concentration can make a voice call, video call and offers to achieve a good percentage of the target. Even though the apps do not have any direct influence on the use of social networks, then the owners should also promptly solve the quires of the customer. This makes more user.

1) Based on the study more verities of benefits, facilities, nearer to the residence, easy approach and convenient time of user are the factors influencing the consumption of social media services.

2) To satisfy the user's needs the social media service founded can create one query apps and necessary action should be initiated upon the queries.

3) To satisfy the user's needs the social media service increases the protection level from the take information.

4) Extending the safety and privacy level of the user may be considered to have more effectively in social media services.

5) To increase the male respondents, the founder of the social media services can introduce some business information apps. Because it's useful to the male respondents.

6) As most of the respondents expect fewer cost services, so the founder can take suggestions regarding the cost of the internet service provided to the users. This will automatically increase the number of respondents and village people also.

Conflict of interest statement and funding sources

The authors declared that they have no competing interest. The study was financed by personal finding. 
Statement of authorship

The authors have a responsibility for the conception and design of the study. The authors have approved the final article.

\section{Acknowledgments}

The authors would like to thank the reviewer for their consideration the further process of the present paper. Thanks to the editor of IRJMIS for the valuable support, time as well as advice.

Athilakshmi, V., \& Chitra, S. (2018). College student attitude towards social media. International Research Journal of Management, IT and Social Sciences, 6(1), 33-41. https://doi.org/10.21744/irjmis.v6n1.481 


\section{References}

Cheung, C. M., Chiu, P. Y., \& Lee, M. K. (2011). Online social networks: Why do students use facebook?. Computers in Human Behavior, 27(4), 1337-1343. https://doi.org/10.1016/j.chb.2010.07.028

Fogel, J., \& Nehmad, E. (2009). Internet social network communities: Risk taking, trust, and privacy concerns. Computers in human behavior, 25(1), 153-160. https://doi.org/10.1016/j.chb.2008.08.006

Geria, A. A. G. A., Maheswari, A. I. A., \& Pemayun, A. G. P. (2018). Social media as promotion trend for increasing tourist visit towards digital era. International Journal of Social Sciences and Humanities, 2(3), 86-94. https://doi.org/10.29332/ijssh.v2n3.204

Kim, Y., Sohn, D., \& Choi, S. M. (2011). Cultural difference in motivations for using social network sites: A comparative study of American and Korean college students. Computers in human behavior, 27(1), 365-372. https://doi.org/10.1016/j.chb.2010.08.015

Mao, J. (2014). Social media for learning: A mixed methods study on high school students' technology affordances and perspectives. Computers in Human Behavior, 33, 213-223. https://doi.org/10.1016/j.chb.2014.01.002

Roblyer, M. D., McDaniel, M., Webb, M., Herman, J., \& Witty, J. V. (2010). Findings on Facebook in higher education: A comparison of college faculty and student uses and perceptions of social networking sites. The Internet and higher education, 13(3), 134-140. https://doi.org/10.1016/j.iheduc.2010.03.002

Stutzman, F., Capra, R., \& Thompson, J. (2011). Factors mediating disclosure in social network sites. Computers in Human Behavior, 27(1), 590-598. https://doi.org/10.1016/j.chb.2010.10.017

Tess, P. A. (2013). The role of social media in higher education classes (real and virtual)-A literature review. Computers in Human Behavior, 29(5), A60-A68. https://doi.org/10.1016/j.chb.2012.12.032 


\section{Biography of Authors}

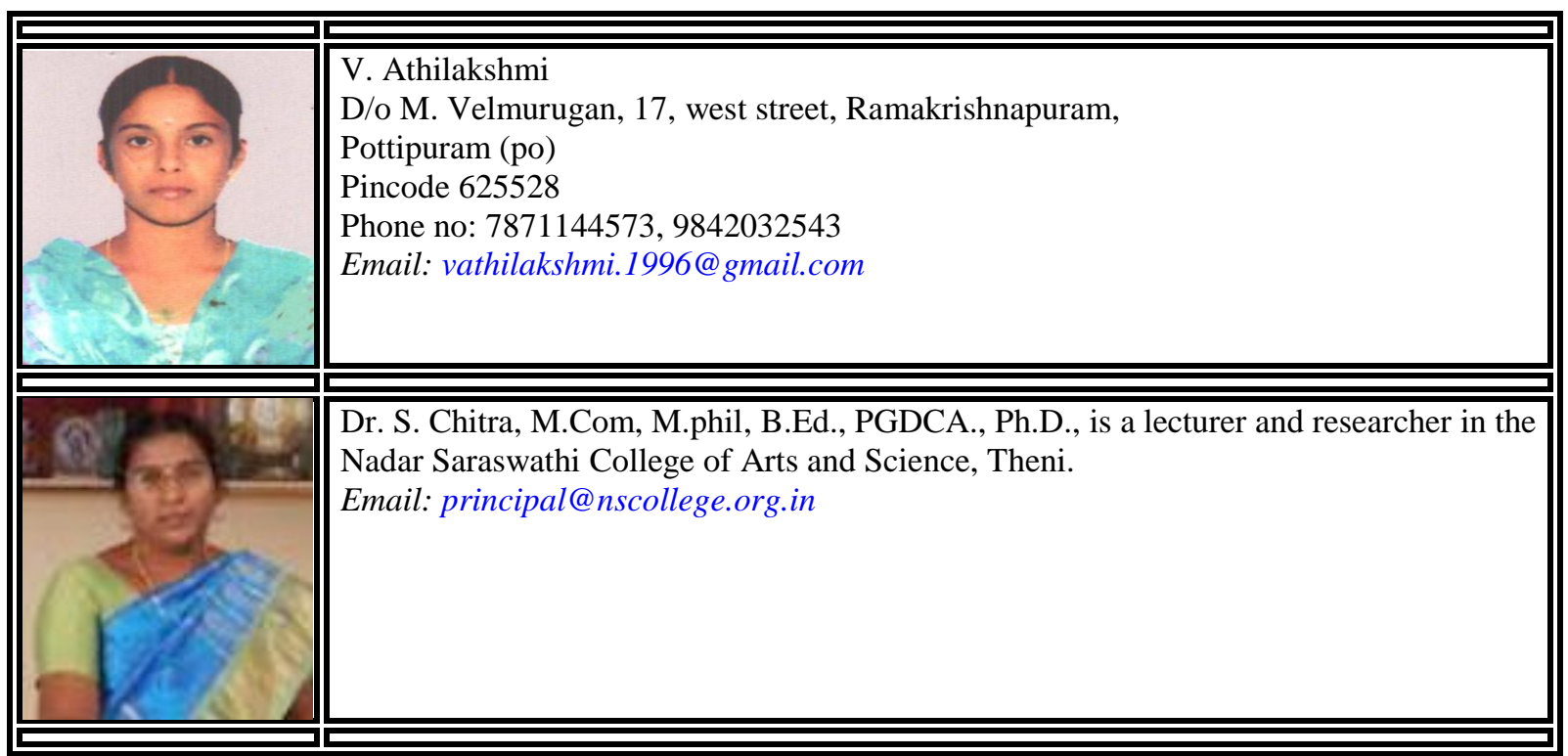

Athilakshmi, V., \& Chitra, S. (2018). College student attitude towards social media. International Research Journal of Management, IT and Social Sciences, 6(1), 33-41. https://doi.org/10.21744/irjmis.v6n1.481 